\title{
COMMUNITY ENGAGEMENT BY UNIVERSITY NURSING SCHOOLS: SURVEY AND CASE STUDIES
}

\author{
N Sibiya, Durban University of Technology; \\ L Netshikweta, University of Venda; \\ J Kgole, University of Limpopo; \\ E Stellenberg, University of Stellenbosch; \\ E Seekoe, University of Fort Hare; \\ HC Klopper, University of Western Cape and North West University of Potchefstroom
}

\begin{abstract}
The purpose of this article is to describe the results obtained from the survey on the involvement of university schools in community engagement and to share the descriptions of exemplary community engagement projects, each selected from the different categories of universities, i.e. research-intensive university, research-teaching balanced university, comprehensive university and a university of technology.

The results show that of the ten schools who responded, all were engaged in communities around them, with projects to improve health services being most common (22 projects), followed by projects to promote health and prevent illness (29 projects). The least popular were projects to develop policy (only 2) and projects to develop new services (8). On average, between 10 and $29 \%$ of academics from each school were involved in the different types of community activities. The number of projects per school varied between 1 and 18 .

The more detailed project descriptions provide a picture of valuable projects both in terms of scope and duration, benefiting communities and schools. The projects often involved research.
\end{abstract}

Keywords: Case Studies; Community engagement

\section{Introduction}

In 1996, Ernest Boyer coined the term 'scholarship of engagement', in an article with the same title. The "scholarship of engagement means connecting the rich resources of the university to our most pressing social, civic and ethical problems ... I have this growing conviction what's also needed is not just more programs, but a larger purpose, a sense of mission, a larger clarity of direction in the nation's life as we move toward century twenty-one". Michigan State University defines scholarship of engagement as the co-creation and application of knowledge, characterized by a relationship that increases both partners' capacity to address issues. In line with these global developments, the White Paper on Higher Education (1997), called upon South African universities to demonstrate social responsibility and their commitment to the common good by making available knowledge-based expertise and infrastructure as they respond to regional and national community needs.

Teaching and research have been the core of the academic enterprise. Since 2007, community engagement has been added as a core responsibility of higher education, alongside research and 
teaching (see Figure 9.1). According to the South African Council on Higher Education (CHE), community engagement has been neglected in South Africa (CHE, 2010). A key objective of community engagement is to promote and develop social responsibility and awareness amongst students of the role of higher education in social and economic development through service programmes. Community engagement is a key priority in university nursing schools. Therefore, it is imperative for nursing schools to be responsive to the diverse needs of the community. According to Gibbons (2007), community engagement should be a core value to an institution and this may be demonstrated in a social contract between society and university science. Such a contract also develops relations of trust that an agreement will be adhered to on both sides.

As FUNDISA embarks on strategies to expand the impact of nursing at higher education institutions and in the community, the need to describe the baseline performance of nursing schools in this area was identified. A survey was conducted by the Practice Portfolio Committee of FUNDISA to describe the extent and types of community engagement at university nursing schools in order to develop a base that could be used to facilitate the development of a community engagement strategy in South Africa. The term 'nursing school' will be used to refer to university nursing schools, departments and divisions.

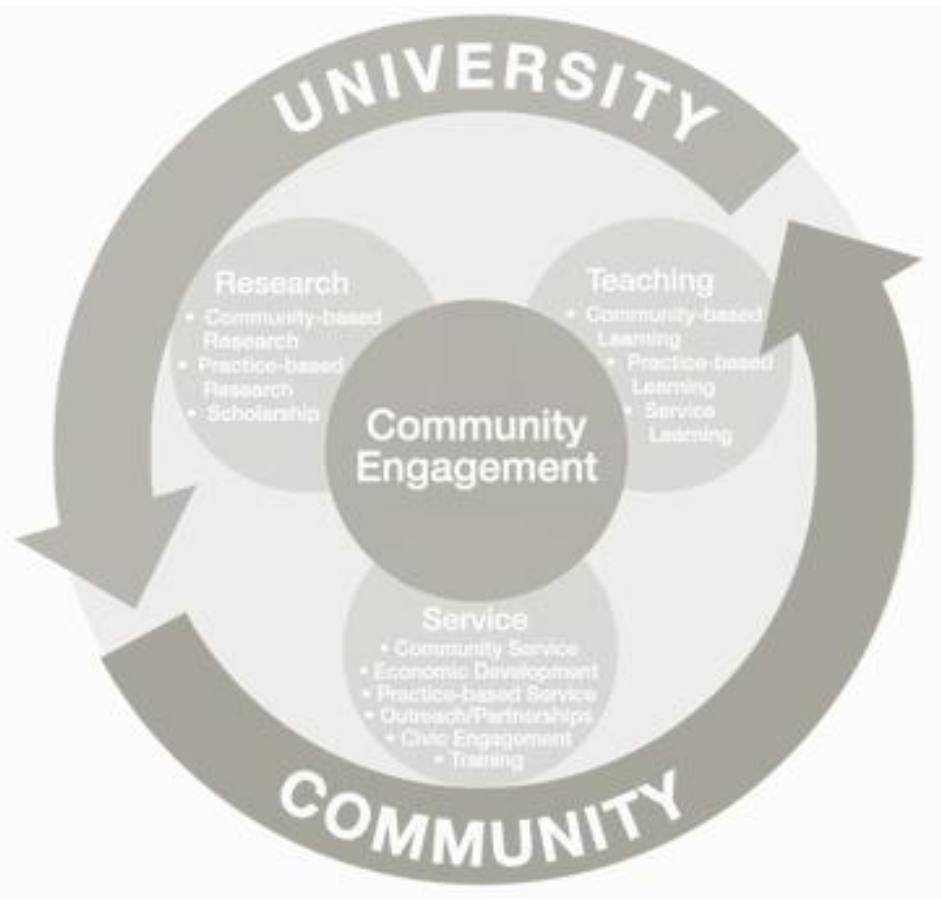

Figure 9.1: Core responsibilities of higher education 


\section{Purpose}

The purpose of this article is to:

1. Describe the results obtained from the survey on the involvement of university schools in community engagement;

2. Share the descriptions of exemplary community engagement projects, each selected from the different categories of universities, i.e. research-intensive university, research-teaching balanced university, comprehensive university, rural university and a university of technology.

\section{Concept clarification}

The following concepts are used in the chapter and described here for clarity.

\section{Community engagement}

CIC (2005: 9) defines community engagement as "the process of working collaboratively with and through groups of people affiliated by geographic proximity, special interest, or similar situations to address issues affecting the well-being of those people".

\section{Social responsibility}

The awareness of social responsibility in higher education was brought about by the introduction of the White Paper on the Transformation of Higher Education in South Africa (1997). The White Paper is the forerunner to the introduction of the fundamental principles for social responsibility within higher education. One of its key goals emphasizes the role of higher education to promote and develop social responsibility and awareness amongst students. The engagement of community service programmes to promote social and economic development should be fostered. In addition, higher education is commissioned to provide and make available expertise and infrastructure for community service programmes to 'demonstrate social responsibility of institutions and their commitment to the common good.' The White paper further emphasizes that the Ministry is receptive to 'the growing interest in community service programmes for students, to harness the social commitment and energy of young people' and is committed to 'feasibility studies and pilot programmes which explore the potential of community service in higher education'.

Higher education responded to the challenge on social responsibility and, with the support of the Ford Foundation, was able to conduct a national survey on community service at the various higher education institutions. Results showed that (i) most institutions included community service in their mission statement; (ii) few institutions had an explicit policy or strategy to operationalise this component in the mission statement; (iii) most institutions had a wide range of community service projects and (iv) most of these projects were initiated by academics and students and not institutionally driven. Based on the results of the survey, a further grant from the Ford Foundation was awarded to the Joint Education Trust in 1998 to form the 'CommunityHigher Education Service partnership (CHESP) initiative (Lazarus et al., 2008). The CHESP set specific objectives which included (i) supporting the development of pilot programmes directly aligned to the mandate of the Education White paper; (ii) to monitor, evaluate and research these programmes; (iii) to use the data generated through this research to inform higher education policy and practice at a national, institutional and programmatic level (Lazarus et al., 2008). 


\section{Scholarship of engagement}

Scholarship of engagement is the umbrella term that encapsulates scholarship in the areas of teaching, research, and service. The term refers to scholarly work ranging from application of academic expertise to community engaged scholarship and is evidenced by the reciprocal partnership the academic has with the community. Engaged scholarship includes collaboration between academics and individuals/groups/communities outside the academy for the mutually beneficial exchange of knowledge and resources in a context of partnership and reciprocity (New England Resource Center for Higher Education). In a nutshell, such scholarship is part of a collaborative process to contribute to the public good. Alternative constructs used include engaged scholarship, community engaged scholarship and community engagement. Of significance are the elements that distinguish engagement scholarship (CIC, 2005):

- Engagement is scholarly: A scholarship-based model of engagement involves both the act of engaging (bringing universities and communities together) and the product of engagement (the spread of discipline-generated, evidence-based practices in communities).

- Engagement cuts across the mission of teaching, research, and service. It is not a separate activity, but a particular approach to campus-community collaboration.

- Engagement is reciprocal and mutually beneficial. There is mutual planning, implementation and assessment among engagement partners.

\section{Methodology}

This was a questionnaire-based survey including all 22 university nursing schools.

\section{Sample}

A structured self-administered questionnaire was distributed to all 22 university nursing schools offering nursing programmes in South Africa. After two reminders, of the 22 nursing schools, 10 submitted completed questionnaires resulting in a $45 \%$ response rate. The following schools participated in the survey:

1. Durban University of Technology

2. North West University (Mafikeng)

3. Stellenbosch University

4. Tshwane University of Technology

5. University of Cape Town

6. University of the Free State

7. $\quad$ University of Limpopo

8. University of Pretoria

9. University of Venda

10. University of the Western Cape
(DUT)

(UNIVEN)

(UWC)
(KwaZulu-Natal)

(North West)

(Western Cape)

(Gauteng)

(Western Cape)

(Free State)

(Limpopo)

(Gauteng)

(Limpopo)

(Western Cape)

\section{Data collection}

The questionnaire consisted of the following sections:

- Projects to improve services in the public sector 
- Projects to develop new health services

- Projects to develop new health policies

- $\quad$ Projects to promote health and prevent illness

In each section, schools were asked to list their projects, indicate start/completion dates and partners in the project, as well as the percentage of academics from the school involved in the project. The second section asked the school to describe its "best" project in more detail, providing the aim and objectives, main activities and achievements. The questionnaire was pre-tested to ascertain its reliability. Pretesting was done by sending the questionnaire to a few academics to check if questions were understandable, and therefore no changes were made to the questionnaire.

\section{Data collection process and analysis}

The questionnaire was distributed via e-mail to all nursing schools. The Heads of School were requested to complete the questionnaire or refer it to the appropriate person. Data collection took place between June and July 2012, with later submissions of questionnaires arriving between August and September 2012. The response rate was not good, despite follow- up (42\%). This was probably related to the fact that few Universities require schools to report on this aspect of their activity, and participation in the survey therefore demanded additional work from already busy academics.

Data was analysed manually by summarizing the data from section 1 of the questionnaire and using section 2 to select an exemplar project for each of the educational institution types taking part in the survey.

Except for the low response rate, the respondents might also not have been certain as to how to classify their own projects. It might have been more appropriate to classify some of the "new service" projects as "service improvement" and vice versa.

\section{Ethical clearance}

The survey was approved by the FUNDISA Practice Portfolio Committee as adhering to ethical guidelines.

\section{Results}

The results extracted from section 1 of the survey indicate that all the schools were involved in at least one community project, while one school was involved in as many as 18 projects. It does not make sense to compare the number of projects per school with each other, since they vary greatly in size. The projects are described in four categories: those to improve services in the public sector (see Table 9.1), projects to develop new health services (see Table 9.2), projects to develop new health policies (see Table 9.3) and projects to promote health and prevent illness (refer to Table 9.4). 
Table 9.1. Projects to improve services in the public sector

\begin{tabular}{|c|c|c|c|c|c|}
\hline School & Projects & $\begin{array}{c}\text { Date } \\
\text { started }\end{array}$ & $\begin{array}{c}\text { Date } \\
\text { complete } \\
\text { d }\end{array}$ & Partners & $\begin{array}{c}\text { \% of } \\
\text { academics } \\
\text { involved }\end{array}$ \\
\hline \multirow[t]{4}{*}{ DUT } & $\begin{array}{l}\text { Project Planning \& Management e.g. } \\
\text { assisting communities to get IDs, } \\
\text { building ramps for the disabled in } \\
\text { industry. }\end{array}$ & 2005 & Ongoing & $\begin{array}{l}\text { Various communities and } \\
\text { Department of Home Affairs }\end{array}$ & 20 \\
\hline & $\begin{array}{l}\text { Willowfountain Group motivated } \\
\text { community to go for circumcision. } \\
\text { NGO will assist with transport of } \\
\text { those who need circumcision to the } \\
\text { nearest clinic. }\end{array}$ & 2011 & Ongoing & $\begin{array}{l}\text { Department of Health, NGO, } \\
\text { Willowfountain community }\end{array}$ & 40 \\
\hline & Waste collection at Willowfountain & 2011 & Ongoing & $\begin{array}{l}\text { Municipality } \\
\text { Councillor and communities }\end{array}$ & 20 \\
\hline & Donation to a crèche. & 2011 & Ongoing & $\begin{array}{l}\text { PEP Stores, crèche teachers, } \\
\text { social workers and Thandanani } \\
\text { NGO, } \\
\text { DoE and businesses }\end{array}$ & 40 \\
\hline NWU & $\begin{array}{l}\text { Improvement of the management of } \\
\text { HIV- exposed babies under } 5 \text { years }\end{array}$ & $\begin{array}{l}\text { Septem } \\
\text { ber } \\
2011\end{array}$ & Ongoing & $\begin{array}{l}\text { DoH (Montshioa stadt clinic), } \\
\text { Mmabatho college of nursing }\end{array}$ & 8 \\
\hline \multirow[t]{2}{*}{ SUN } & $\begin{array}{l}\text { Pilot study in inter-partner violence } \\
\text { in the Witzenburg sub-district: } \\
\text { teaching communities and registered } \\
\text { nurses. }\end{array}$ & 2011 & Ongoing & PGWC & 5 \\
\hline & $\begin{array}{l}\text { Short courses for registered nurses } \\
\text { e.g. comprehensive management of } \\
\text { antiretroviral \& TB drugs, leadership } \\
\text { and scientific writing. }\end{array}$ & 2011 & $\begin{array}{l}\text { Ongoing } \\
\text { at 3- } \\
\text { monthly } \\
\text { intervals }\end{array}$ & PGWC & 25 \\
\hline \multirow[t]{2}{*}{ TUT } & $\begin{array}{l}\text { UNEDSA community-based primary } \\
\text { healthcare }\end{array}$ & 2009 & Ongoing & City of Tshwane Municipality & 20 \\
\hline & Onthatile & 2005 & Ongoing & Grace Bible Church & 5 \\
\hline \multirow[t]{2}{*}{ UCT } & $\begin{array}{l}\text { Development of nursing services for } \\
\text { sexual assault victims and survivors in } \\
\text { the Western Cape }\end{array}$ & 2008 & Ongoing & $\begin{array}{l}\text { Department of Forensic } \\
\text { Medicine, UCT, Western Cape } \\
\text { Department of Health (Maternal } \\
\text { and Child Health Cluster) }\end{array}$ & 28 \\
\hline & $\begin{array}{l}\text { Western Cape Nursing Research } \\
\text { Forum }\end{array}$ & 2000 & Ongoing & $\begin{array}{l}\text { Public Nursing Services, including } \\
\text { Groote Schuur Hospital, Red } \\
\text { Cross Children's Hospital and } \\
\text { other local hospitals }\end{array}$ & 100 \\
\hline \multirow[t]{2}{*}{ UFS } & PHC Health Education & 2006 & Ongoing & $\begin{array}{l}\text { Mangaung community, PHC } \\
\text { clinics and CHCs, Old Age Homes, }\end{array}$ & 8 \\
\hline & Wound care in the community & 2007 & Ongoing & $\begin{array}{l}\text { Patients from Bloemfontein } \\
\text { Private Homes, Old Age Homes, } \\
\text { Universitas Hospital, Wound Care } \\
\text { Clinics }\end{array}$ & 8 \\
\hline
\end{tabular}




\begin{tabular}{|c|c|c|c|c|c|}
\hline UL & $\begin{array}{l}\text { Moletsi Centre for mentally } \\
\text { handicapped children }\end{array}$ & 1997 & Ongoing & $\begin{array}{l}\text { National Development Agency } \\
\text { (NDA), } \\
\text { Dept of Social Development, } \\
\text { National Council of African } \\
\text { Women (NCAW), } \\
\text { Interdenominational Churches }\end{array}$ & 13 \\
\hline \multirow[t]{6}{*}{ UP } & $\begin{array}{l}\text { Unedsa project - CoP for gender- } \\
\text { related violence }\end{array}$ & 2010 & Ongoing & $\begin{array}{l}\text { University of Limpopo (Medunsa, } \\
3 \text { crisis centres in Tshwane } \\
\text { district) }\end{array}$ & \\
\hline & $\begin{array}{l}\text { In-service training Tshwane District } \\
\text { Hospital }\end{array}$ & 2012 & Ongoing & Dr M. Yazbek & \\
\hline & $\begin{array}{l}\text { Standardization of Midwifery } \\
\text { Procedure manuals }\end{array}$ & 2012 & $\begin{array}{l}7 / 09 / 201 \\
2\end{array}$ & Dr Kaye Peterson & \\
\hline & $\begin{array}{l}\text { COP for HIV and AIDS: Partnerships } \\
\text { with district hospitals }\end{array}$ & 2010 & Ongoing & $\begin{array}{l}\text { Tshwane } \\
\text { Jubilee Healthcare providers }\end{array}$ & \\
\hline & In-service training & 2000 & Ongoing & Service personnel & \\
\hline & Daspoort project & 2006 & Ongoing & Health Services & \\
\hline Univen & $\begin{array}{l}\text { Knowledge and attitudes of pregnant } \\
\text { women towards antenatal care } \\
\text { services at Shigalo Village, Vhembe } \\
\text { district. }\end{array}$ & 2011 & $\begin{array}{l}\text { March } \\
2012\end{array}$ & $\begin{array}{l}\text { Department of Nursing } \\
\text { Dept Nutrition } \\
\text { Dept Psychology }\end{array}$ & 100 \\
\hline UWC & $\begin{array}{l}\text { Self-leadership of traumatized youth } \\
\text { in Region B clinics of Johannesburg }\end{array}$ & 2011 & Ongoing & Region B clinics in Johannesburg & \\
\hline
\end{tabular}

Twenty-two projects were reported by ten schools with a focus on improvement of services in the public sector, inclusive of hospital or community-based settings. These projects span the period 1997 to 2013, with the bulk (9 projects) initiated in 2011. Except for two projects, all are of an ongoing nature. Of the ten universities who completed the survey, two did not indicate the percentage of staff involvement, but between the remaining eight universities, staff involvement with these community projects is, on average, $30 \%$, ranging from between $5 \%$ and $100 \%$. 
Table 9.2. Projects to develop new health services

\begin{tabular}{|c|c|c|c|c|c|}
\hline School & Projects & $\begin{array}{l}\text { Date } \\
\text { started }\end{array}$ & Date completed & Partners & $\begin{array}{c}\% \text { of academics } \\
\text { involved }\end{array}$ \\
\hline SUN & Rural Clinic in Worcester & 2012 & Ongoing & IPLO \& Ukwanda & 25 \\
\hline TUT & UNEDSA antenatal clinic & 2012 & Ongoing & $\begin{array}{l}\text { City of Tshwane } \\
\text { Municipality }\end{array}$ & 5 \\
\hline \multirow[t]{2}{*}{ UFS } & Parent skill empowerment & 2007 & Ongoing & $\begin{array}{l}\text { Families of pre-school } \\
\text { children, community-based } \\
\text { centre, students and } \\
\text { facilitators }\end{array}$ & 3 \\
\hline & $\begin{array}{l}\text { Training of lay health workers and } \\
\text { partnership development }\end{array}$ & 2008 & Ongoing & & 4 \\
\hline \multirow[t]{4}{*}{ UP } & Health post at Alaska Viva & 2012 & Ongoing & & \\
\hline & Introduction of primary health care & 2005 & Ongoing & $\begin{array}{l}\text { Department of Education } \\
\text { Community }\end{array}$ & 3 \\
\hline & School Health Services & 2012 & Ongoing & Department of Education & 20 \\
\hline & Enabling churches to fight child abuse & 2012 & Ongoing & $\begin{array}{l}\text { Women and youth in the } \\
\text { MRCC, } \\
\text { theology students and } \\
\text { ministers of religion of the } \\
\text { MRCC }\end{array}$ & \\
\hline
\end{tabular}

In terms of the reported projects that focus on the development of new health services, four universities responded that they are involved with such initiatives, totaling 8 projects. The initiation date ranges from 2005 to 2012, with 5 projects (62.5\%) initiated in 2012, and all eight projects are of an ongoing nature.

\section{Table 9.3. Projects to develop new health policies}

\begin{tabular}{|c|c|c|c|c|c|}
\hline School & Projects & $\begin{array}{l}\text { Date } \\
\text { started }\end{array}$ & Date completed & Partners & $\begin{array}{l}\text { \% of academics } \\
\text { involved }\end{array}$ \\
\hline \multirow[t]{2}{*}{ UCT } & $\begin{array}{l}\text { Vision } 2020 \text { to plan eye- care services } \\
\text { and the number of ophthalmic nurses } \\
\text { needed in each district }\end{array}$ & 2010 & Ongoing & $\begin{array}{l}\text { UCT Community Eye } \\
\text { Health Institute, PGWC, } \\
\text { Ophthalmologists, } \\
\text { Ophthalmic Nurses from } \\
\text { each District, Specialist } \\
\text { Ophthalmologists from } \\
\text { UCT \& US Optometrists }\end{array}$ & 14 \\
\hline & $\begin{array}{l}\text { Drafted a policy for vision and } \\
\text { hearing screening of school children } \\
\text { at national level on behalf of the } \\
\text { Ophthalmological Society of South } \\
\text { Africa (OSSA) requested by the } \\
\text { Minister of Health. }\end{array}$ & 2011 & Ongoing & $\begin{array}{l}\text { UCT Division of Nursing \& } \\
\text { Midwifery, UCT Division } \\
\text { of Ophthalmology, OSSA }\end{array}$ & 14 \\
\hline
\end{tabular}


Of interest is that only one university indicated that it was involved with projects to develop new health policies. UCT has two such projects, one established in 2010 and one in 2011, with 14\% of staff participating in these ongoing projects. In the light of the continuous need for nurses to be involved in shaping health policy, this is an area of specific concern, as so few universities are involved in these types of projects.

\section{Table 9.4. Projects to promote health and prevent illness}

\begin{tabular}{|c|c|c|c|c|c|}
\hline School & Projects & Date started & $\begin{array}{l}\text { Date } \\
\text { completed }\end{array}$ & Partners & $\begin{array}{l}\% \text { of academics } \\
\text { involved }\end{array}$ \\
\hline \multirow[t]{2}{*}{ DUT } & $\begin{array}{l}\text { Youth empowerment programmes } \\
\text { on prevention of substance abuse } \\
\text { and teenage pregnancy }\end{array}$ & 2010 & Ongoing & $\begin{array}{l}\text { NGOs, Ward Councilors } \\
\text { and communities }\end{array}$ & $25 \%$ \\
\hline & Soup kitchen & 2011 & Ongoing & $\begin{array}{l}\text { Chiefs, indunas Mpumuza } \\
\text { community and PHC } \\
\text { clinics, Cindi NGO, } \\
\text { Businesses e.g. Albany } \\
\text { Bakery }\end{array}$ & $40 \%$ \\
\hline NWU & $\begin{array}{l}\text { Empowerment project to reduce } \\
\text { teenage pregnancy and substance } \\
\text { abuse in a village community }\end{array}$ & May 2012 & Ongoing & DoE & $40 \%$ \\
\hline \multirow[t]{3}{*}{ SUN } & School Health Promotion & 2011 & Ongoing & None & $20 \%$ \\
\hline & Maties Community health Services & 2006 & Ongoing & $\begin{array}{l}\text { Faculty of Medicine \& } \\
\text { Health Sciences }\end{array}$ & $20 \%$ \\
\hline & $\begin{array}{l}\text { Local integrated Network of Kuils } \\
\text { River }\end{array}$ & 2001 & Ongoing & Community of Kuils River & $30 \%$ \\
\hline TUT & $\begin{array}{l}\text { UNEDSA community-based primary } \\
\text { healthcare }\end{array}$ & 2009 & Ongoing & $\begin{array}{l}\text { City of } \quad \text { Tshwane } \\
\text { Municipality }\end{array}$ & $20 \%$ \\
\hline \multirow[t]{2}{*}{ UCT } & $\begin{array}{l}\text { Eye health awareness campaign, } \\
\text { vision screening and eye } \\
\text { examination of infants and children } \\
\text { in informal settlements }\end{array}$ & 2011 & Ongoing & $\begin{array}{l}\text { Midwifery PG Dip } \\
\text { Ophthalmic nursing } \\
\text { students, SHAWCO }\end{array}$ & $14 \%$ \\
\hline & $\begin{array}{l}\text { Eye health awareness campaigns, } \\
\text { vision screening and eye } \\
\text { examination of infants, children } \\
\text { and adults in remote areas of the } \\
\text { West Coast }\end{array}$ & 2012 & Ongoing & $\begin{array}{l}\text { PG Dip Ophthalmic } \\
\text { nursing } \quad \text { students, } \\
\text { Christen-Blinden Mission }\end{array}$ & $14 \%$ \\
\hline UFS & $\begin{array}{l}\text { Students' projects on community } \\
\text { profile and life skills }\end{array}$ & 2002 & Ongoing & Various communities & \\
\hline UL & $\begin{array}{l}\text { Moletsi Centre for mentally } \\
\text { handicapped children }\end{array}$ & 1997 & Ongoing & $\begin{array}{l}\text { National Development } \\
\text { Agency, } \\
\text { Dept of Social } \\
\text { Development, } \\
\text { National Council of } \\
\text { African Women (NCAW), } \\
\text { Inter-denominational } \\
\text { Churches (Women's } \\
\text { League) }\end{array}$ & $13 \%$ \\
\hline
\end{tabular}




\begin{tabular}{|c|c|c|c|c|c|}
\hline \multirow[t]{8}{*}{ UP } & Community assessment project & 2012 & 12 July 2012 & $\begin{array}{l}\text { BCUR III students } \\
\text { Community } \\
\text { Lecturers }\end{array}$ & 5 persons \\
\hline & $\begin{array}{l}\text { Alaska Viva village-James Care Take } \\
\text { On Family data collection. }\end{array}$ & 2012 & $\begin{array}{l}\text { October } \\
2012\end{array}$ & $\begin{array}{l}\text { BCUR first years and } 2 \\
\text { lecturers }\end{array}$ & 2 \\
\hline & $\begin{array}{l}\text { Development of a questionnaire to } \\
\text { assist with record-keeping and } \\
\text { better ANC patient care }\end{array}$ & 2012 & Ongoing & Dr P.F. Mahuma & 1 \\
\hline & $\begin{array}{l}\text { Health promotion for families with } \\
\text { HIV and AIDS }\end{array}$ & 2009 & Ongoing & $\begin{array}{ll}\text { Moretele } & \text { Sun-Rise } \\
\text { Hospice, DoH } & \\
\end{array}$ & 2 \\
\hline & Health promotion school & 2008 & Ongoing & $\begin{array}{ll}\text { Moretele } & \text { Sun-Rise } \\
\text { Hospice, DoH } & \\
\end{array}$ & 10 \\
\hline & Candle Wise Project & 2012 & Ongoing & $\begin{array}{l}\text { Child safe, } \\
\text { Community members, } \\
\text { Children and } \\
\text { Foundation Phase } \\
\text { Learner Educators }\end{array}$ & 5 \\
\hline & Injury prevention & 2012 & Ongoing & TUT & 3 \\
\hline & $\begin{array}{l}\text { Enabling churches to fight child } \\
\text { abuse }\end{array}$ & 2012 & Ongoing & $\begin{array}{l}\text { Women and youth } \\
\text { groups in MRCC, } \\
\text { theology students and } \\
\text { ministers of religion of } \\
\text { the MRCC }\end{array}$ & \\
\hline \multirow[t]{10}{*}{ UWC } & $\begin{array}{l}\text { Mental Health Awareness Outreach } \\
\text { Programme }\end{array}$ & 2011 & Ongoing & Inter-disclinary T \& L* & \\
\hline & Training of home-based carers & 2010 & Ongoing & Inter-disciplinary T \& L & \\
\hline & $\begin{array}{l}\text { Skills development for elderly and } \\
\text { disabled clients }\end{array}$ & 2010 & Ongoing & Inter-disciplinary T \& L & \\
\hline & $\begin{array}{l}\text { Support Group for terminally ill } \\
\text { clients at St. Luke's Hospice }\end{array}$ & 2010 & Ongoing & Inter-disciplinary T \& L & \\
\hline & Women's Health Project & 2010 & Ongoing & Inter-disciplinary T \& L & \\
\hline & Tri-Schools project & 2010 & Ongoing & Inter-disciplinary T \& L & \\
\hline & Klein Begin Crèche & 2010 & Ongoing & Inter-disciplinary T \& L & \\
\hline & $\begin{array}{l}\text { Skills development at the Beacon } \\
\text { Valley Frail Care centre }\end{array}$ & 2010 & Ongoing & Inter-disciplinary T \& L & \\
\hline & $\begin{array}{l}\text { Stimulation of early childhood } \\
\text { development in the Heinz Park } \\
\text { community }\end{array}$ & 2010 & Ongoing & Inter-disciplinary T \& L & \\
\hline & $\begin{array}{l}\text { Heaven Shelter: support group for } \\
\text { abused and teenage mothers }\end{array}$ & 2010 & Ongoing & Inter-disciplinary T \& L & \\
\hline \multicolumn{6}{|c|}{ Average academics involved: $24 \%$} \\
\hline
\end{tabular}

* Inter-disciplinary Teaching and Learning

It is evident from the responses that universities are, to a large exteny, involved in projects focusing on the promotion of health and prevention of illness, with 29 projects listed from nine schools. The origin of the projects varies between 1997 and 2012, with most of them initiated in 2010. Universities have indicated that between $13 \%$ and $40 \%$ of their staff are involved with these projects, with an average amongst the projects of $23.8 \%$. 


\section{Project Descriptions}

This section presents the project descriptions from different universities to illustrate good practices.

\section{Research-intensive university: A project from the University of Stellenbosch}

Title: An Integrated Community Development Model in Kuils River

A doctoral study (Stellenberg, 2000) identified several factors profoundly influencing the health status of people in the Western Cape. Social, educational and cultural deprivations were the dominant features within this community of 50000 under study in Kuils River. Kalkfontein is the poorest area in Kuils River with a population of 10000 and a high concentration of liquor and drug outlets. At the time of the study, 25.8\% of inhabitants lived in informal settlements (Erasmus, Mans \& Jacobs, 2006). Factors identified in the area that adversely influenced health included unemployment, low socio-economic levels and crime (Stellenberg et al., 2008). The social habits of this community revealed an inordinate amount of substance and alcohol abuse. Poor nutritional status, lifestyle issues (e.g. lack of exercise) and high levels of stress were additional defining characteristics of this community. These factors led to $97 \%$ of the economically active persons in this community moving towards premature death, with only $3 \%$ developing towards a higher level of wellness (Stellenberg, 2000). This has a devastating impact on the life expectancy of the population and a profound effect on the economy, further compounded by the AIDS / HIV pandemic. At a young age, people would become too sickly to be productive and contribute to the economy.

A holistic, integrated approach to development was embarked upon with a view to bring about a positive change in the community. Major stakeholders of the community were engaged in a partnership, enabling them to identify the social pathologies and needs of the community. Together, this unit addressed the challenges holistically and identified priorities for intervention. The immediate projects identified for intervention were the (i) Social Worker Project (ii) Pro-family Project, (iii) Establishment of a Kuils River Network, (iv) Project for Learners in Leadership and Team-building (v) Project for Literacy and Numeracy Support for Learners at Kalkfontein Primary School (vi) Homework Support Programmes and a (vii) Training Project for Volunteers with Counseling Skills.

This study fitted in with the strategic vision of Stellenbosch University for community engagement. It drew from the intersectoral resources of the university, with particular reference to the Department of Interdisciplinary Health Sciences (Faculty of Medicine and Health Sciences) and Department of Curriculum Studies (Faculty of Education). Having established a relationship of trust with the community of Kuils River, in partnership with the University, the next phase was to establish a teaching platform for university departments. Consequently, university departments were now able to meet specific curriculum needs within the community. The Faculty of Medicine and Health Sciences at Stellenbosch University had the objective, as stated in their business plan, that $50 \%$ of student education and training should take place in the community by 2007 . The Department of Interdisciplinary Health Sciences, due to its professional, health and educational composition, spearheaded this.

The first discipline to utilize this teaching platform was the Occupational Therapy Discipline that had been placing students at a Primary School in the area since 2003. It was then envisaged that placement of these students could be expanded to the newly opened Kalkfontein Primary School situated in the poorest area. The Theology Faculty had completed a major research project providing the Kuils River 
Network with a data base for Kuils River (Erasmus, Mans \& Jacobs, 2006). The Social Work Department introduced a "Buddy System" in which a buddy was paired with a learner and then mentored the learner. From 2003, nursing students conducted health days which included health screening and assessment of patients. This activity assisted nursing students to reach outcomes set for Primary Health Care and General Nursing. With the introduction of the Matie Community Service, a health service opportunity was created for the community, but also provided a teaching platform for nursing and medical students. Learning opportunities were created for these students in assessing patients, diagnosing, proposing treatment and referring patients to Day Hospitals. Proposed master's degree studies and undergraduate research projects were planned for the area, including investigations into "The use of Methamphetamine among Primary School Children" and "The knowledge about HIV/Aids of persons living in Kalkfontein". Future expansions to other faculties and departments were planned.

- $\quad$ The Social Worker Project

In the Western Cape, the Kuils River community continued to experience the highest incidence of sexual abuse in the province over weekends (Statistics South African Police Services Kuils River, 2004). As an interim measure, the need for a social worker at a primary school was identified. A three-year project was partially implemented in collaboration with Irista Primary School in Kuils River, Stellenbosch University and a shipping company that partially funded the project. A total of 612 new cases were managed during this period, of which $40.5 \%$ (247) were physically abused and exposed to domestic violence; $36.6 \%$ (224) were treated for substance abuse and behavioural problems; $9.5 \%$ (58) were treated for sexual abuse, which included rape, sodomy and prostitution; 6.2\% (38) were treated for emotional problems and $0.5 \%$ (3) fell pregnant during this period. Results were communicated to the Western Cape Minister of Education, Cameron Dugmore. On the strength of evidence of abuse at this school, a task team was appointed by the Minister of Education to investigate the feasibility of introducing social workers into primary schools in other areas which led to the formulation of policy addressing intensive learner support at schools.

\section{- $\quad$ Profamily Project}

The Kuils River Profamily Action Group was formed, consisting of members from NGOs, education, churches, South African Police Services, Stellenbosch University and community members, with $\mathrm{Dr}$ Stellenberg as project leader to strengthen families by introducing long-term interventions, coaching, and transfer of skills. Community engagement projects introduced in the community included: parenting skills development; workshops for the development of counselling skills of volunteers to counsel abused victims; health days attracting 120 persons, which included activities such as health education and health screening.

\section{- $\quad$ Kuils River Network}

The need was identified to form 'The Local Integrated Network of Kuils River' (L.I.N.K.) with the logo HAMBISANANI: 'Let us walk together'. L.I.N.K enjoyed the support of the office of the Premier of the Western Cape and was identified by the Western Cape Province as a pilot study for other towns in the province. The purpose of L.I.N.K was to transform the town by linking all stakeholders of Kuils River in a 
holistic approach towards development. The first meeting of the Network was attended by 51 representatives from various organizations, government departments and churches. A "Bosberaad"/ Indaba /Bush Meeting" was held, during which a name was decided upon, as well as the vision, mission, logo and objectives for the network. A five-year project of transformation through development was decided upon and implemented. The overall goal was towards the total well-being of all living in the town of Kuils River.

Long-term primary objectives include: holistic development; poverty alleviation; job creation; preventing crime; identifying and addressing all social pathologies; up-skilling the community; breaking down all social, economic, political, racial and cultural barriers; improving the literacy rate of the communities. Streamlining services acts as a filter to prioritize services and projects, as well as a mechanism to establish relevant programmes and projects and seek financial support for these projects, liaising with all stakeholders (including Government Departments). It was envisaged to establish Kuils River as a benchmark against which other communities could measure themselves. The intermediate objective was to establish sub-committees with specific functions such as prevention of substance abuse, homework support programmes and literacy and numeracy support for learners at the school. The short-term goals were to link all stakeholders who had not as yet established a partnership with L.I.N.K.; to introduce literacy and numeracy support for learners at the school, as well as a prevention of substance abuse programme, leadership and team-building programmes for high school learners, and the introduction of a literacy programme for adults.

\section{- Winter school holiday programmes}

The introduction of winter school holiday programmes became essential to protect vulnerable children who might become victims of the evils of society during school holidays. The programmes were initially offered over a period of six days, but were later extended to cover the full holiday period in 2007. This programme was part of the safe schools project, to protect children during the holidays and simultaneously to develop them into good citizens. In 2010 during the World Cup, a four-week holiday programme in collaboration with stakeholders hosted a comprehensive holiday programme. Funding was provided from various sources.

Through these initiatives:

- A L.I.N.K./Education Department partnership programme was later established to support the development of communities, an initiative launched by the Honorable Minister of Education.

- HIV/AIDS Project

Workshops entitled "HIV comes to the party" presented the science of HIV and how it leads to autoimmune disease (AIDS). The process was interactive, using role play and model war games, followed by a "surprise party" demonstrating HIV transmission. The workshops were presented in groups of 30-40 learners from Grades V to Grade XI. Metaphors, role play and 'street speak" were used. The purpose of the study was to determine the extent to which basic knowledge on the science of HIV/AIDS was retained after a peer educational initiative (Stellenberg \& Corfield, 2013). An adapted version of the workshop was presented to all learners which included 17 schools from Grade R. 


\section{Research-Teaching Balanced University: A project description from the University of Fort Hare}

Title: Integration of problem-based learning (PBL) to community-based education (CBE) and research: Embracing nursing scholarship

South Africa does not seem to be able to achieve MDG goals 4 and 5 of reducing child, neonatal and maternal mortality rates. Seventy-five per cent of children are still dying, 23000 in their first four weeks of life. 23000 are stillborn and closely linked to 1660 maternal deaths (Lancet, 2012: 4). The National Health Minister identified the need to re-engineer PHC in order to prepare for implementation of the NHI. Re-engineering PHC and the introduction of National Health Insurance leads to a major political reform agenda, calling for Health Leaders to function differently.

The Eastern Cape Province (ECP) includes large rural, peri-urban and urban communities. The province covers about 169580 square kilometers, which is $13.9 \%$ of the land area of South Africa. It has a population of 6436763 million, 88\% of which are black, of whom a large majority live in the former homelands of the Transkei and the Ciskei. Fifty per cent (50\%) of the population resides in less than a third of the province's land. The ECP has twenty six (26) municipalities and a population density of 41 persons per square kilometer in an area of 169580 square kilometers (SSA, 2003), suggesting considerable scope for making more effective use of available land to meet the needs of both human and stock populations in the province. Various types of health facilities such as seven hundred and forty nine (749) clinics, ten health centres, forty seven (47) district hospitals, two regional hospitals and three tertiary hospitals exist in the province, while facilities that contribute to, or promote health are insufficient. There are no proper recreational facilities in the rural areas, except for football fields and a few community halls which are available to young people.

The residents of the local communities used to cultivate their land and survived on ploughing their fields and planting various types of farm produce. They were indeed self-sufficient in providing themselves with enough food to survive. Furthermore, employment opportunities were guaranteed on whiteowned farms and plantation forests. However, the peoples' life style in this province has greatly changed. The land that used to provide food and an income is lying bare and unused, for the most part. At the same time, in spite of the existence of a large number of public health facilities in the ECP, the sustainable quality of health is negatively affected by problems such as lack of leadership in the provision and delivery of health services (poor management of finances, shortage of personnel, lack of distribution of medication) leading to the province being placed under administration by the National Department of Health. There is also the serious problem of pursuing isolated goals that fail to exploit crucial synergies between health and nutrition, as well as clean and healthy environments. Strengthening individual capacities to procure health services is also an essential component of a sustainable development strategy.

The province is characterised by high teenage pregnancy and a high disease profile, including communicable diseases (HIV/AIDS, TB), and non-communicable diseases (Metabolic Syndrome, mental illness), as well as childhood illness (measles, mumps, diarrhea, late diagnosis of diseases and disabilities) and violence in families resulting in high death rates. There is a need for improvement of the quality of life of women, children and communities through ensuring sustainable, quality healthcare provision that has a strong livelihood focus. Appropriate strategies for women and children in order to be empowered and to develop the necessary resilience to alleviate poverty in the ECP have remained 
elusive. The policy framework for fast-tracking the integration of the rural population into the mainstream economy and create a healthy and productive citizenry has been promoted, and since the late 1990s has received both national and international support in order to bring about change in South Africa. However, change has been either slow or non-existent, and concerns are growing about the current and prospective levels of despondency and destitution in the country.

In the 2011 Nursing Summit, the Minister of Health announced his plan to re-engineer Primary Health Care in order to implement NHI. Fifty-two districts were identified to pilot NHI in order to develop models customised to the needs of the country. The need for development of National Core Standards to the Public Health Facilities for Quality of Health Care, as preparation for the $\mathrm{NHI}$, became evident.

The Medium Term Expenditure Framework (MTEF) (2009) and Vision (2025) emphasise rural development, food security and land reform, access to quality education, improved healthcare, environmental sustainability and cohesive and sustainable communities. The National Plan for Higher Education (2000: 5) indicated that universities are expected to contribute towards the empowerment and resilience of communities.

The Department of Nursing Science (DNS) identified the need to respond to the call for universities to demonstrate social responsibility and their common good by making available expertise and infrastructure for mentoring and empowering women and their children in communities to develop a resilience to poverty. The University of Fort Hare, through its research strategy, emphasises the importance of linking research to teaching and community engagement. The DNS aligned its research, teaching, learning and assessment with the strategic objectives of the university. This was done through transforming research in teaching and learning using the problem-based learning (PBL) and community based education (CBE) method, where curriculum renewal is foreseen. Students develop research projects within three political wards: Amalinde Forest (Ward 16), Scenery Park (Ward 5) and Kubusi Village and team up with Ward-Based Primary Health Care Teams, NGOs and FBOs. This is in line with the strategy for re-engineering PHC.

Academic staff members prepare communities for placement of students as part of curriculum development. The fourth-year nursing students visit communities under the guidance of their lecturers, who received extensive training as PLB-CBE facilitators. The course outcome requires students to observe the environment, identify community health needs and conduct profiles. Students are expected to make a community diagnosis and present their needs to community members. This is done though a meeting where communities are supported to prioritise their requirements. These are translated into projects by students which include community members as participants. The DNS holds annual community engagement days where students present the results of their interventions in the form of research papers. Communities, academics and clinical practitioners are invited to these occasions. The DNS students presented the following projects which they implemented in collaboration with the communities at Amalinde Forest and Scenery Park.

Amalinde Forest: Ward 16 and Scenery Park: Ward 5

The community of Ward 5 was seriously fatigued, which resulted in them chasing the DNS students out, indicating that they did not see any value in their visits. Since the introduction of PBL-CBE, the local counselor invited the PBL-CBE coordinator and students back, after having learned and read from the newspapers about the difference they were making in Ward 16. 
DNS students, ranging from first- to fourth-year undergraduates, under the guidance of their facilitators, educated communities and collaboratively implemented different projects within 5 sections of both wards.

- In one section of the ward, the community complained about the inability of members to care for the environment (garbage disposal). The environmental care project involved education about how people could work together with communities on waste disposal.

- Students identified that children under the age of six were sleeping on the cement floor and donated carpets to the crèche.

- $\quad$ Students bought vegetable seeds and gardens were established for the crèche and the clinic. They also introduced soup kitchens for patients at the clinic and for children younger than six years of age at the crèche.

- During home visits, students identified TB, HIV and AIDS defaulters and detected diseases like hypertension. Patients were referred to the clinic.

- One group of fourth-year students gave health education and contributed food and clothes to 70 families in an informal settlement.

The community interest in the collaboration resulted in a memorandum of understanding being signed between the local councilor of Ward 16 and non-governmental communications to partner with the DNS by using undergraduate students.

One of the university strategic objectives emphasises internationalization which is achieved through building relations and capacity through an exchange of students with international partner universities such as the Elizabeth City State (for academics and undergraduate students) Johns Hopkins (for postgraduate students and academics for research capacity, pre-doctoral training and public health methodologies) and Harvard (academic staff and post-doctoral students for leadership in public health and leadership fellowship) in the United States of America. The exchange involves attendance of conferences to present papers locally and internationally which will increase internationalisation. The third strategic objective is achieved through collaboration with stakeholders such as Departments of Health, Education, Agriculture and Social Development, and Local Municipalities with relevant academic departments as supported by MTEF (2009) and Vision (2025), to ensure social dialogue and the sharing of a vision of growth and development as a nation. Strategic Objective four encourages the creation of an enabling environment which is evidenced by recruiting honours', Master's, Doctoral and PostDoctoral students, as well as academic staff, to identify research topics to conduct pure, applied and intervention research. This includes monitoring the health status of the community to establish compliance with the MDGs and the National Core Standards of public health facilities in order to evaluate quality healthcare as part of preparation for the NHI (King, 2003: 25). Strategic objective seven relates to critical human capital development as a priority skill, and is aligned, through recruitment of postgraduate students and new staff, with the community or research projects. Research skills are achieved through inter- and trans-disciplinary interaction amongst faculties and visiting researchers. Collaborative research, , presenting papers at conferences and writing together for publication creates a vibrant, equitable and sustainable environment amongst faculty and students both locally and internationally. There is an understanding that, through knowledge-sharing within disciplines, a new environment and culture of learning will emerge. The mission regarding university alignment is 
achieved through active participation by community women and children in public health projects. They are enabled so that they have access to information and enter into contractual agreements in projects that ensure that they are mentored so as to develop resilience. Communities are encouraged to decide on how to organize themselves to participate in health activities that promote sustainable health (Steelman and Carmin, 2001: 10; Imperial, 1999: 90).

\section{Comprehensive University: A project description from the University of Limpopo (Turfloop Campus)}

Title: Establishment of a centre for mentally handicapped children in the Moletši area.

- Description of the Moletši area:

The Moletši area presently consists of 130 villages and each village is led by an induna with, upon average, 650 households. The area is a semi-rural area. Each village has approximately three primary schools and two high schools. Moletši centre is situated $30 \mathrm{~km}$ from the town of Polokwane, next to a tarred road and electric line and adjacent to a cross road. The centre is situated at a central place and is easily accessible for all the villages from North, East, South and West.

- $\quad$ Rationale for establishing the centre

The centre needed to be established after identifying children at home and in lower primary schools. The children who were staying at home were found to be roaming around in the community streets without an aim, being abused by some community members and not getting the necessary care, treatment and rehabilitation.

- $\quad$ Pre-entry into the area

Negotiations started in March 1998. The then University of Limpopo Head of the Department of Nursing Science, Prof. Julia Mmekwa, went with Dr J.C Kgole to the Moletši Chief's kraal to meet the key leaders of the community. Chief Kgabo Moloto III and his 100 indunas were present, as well as representatives of each sector of the community such as a political organisation, the taxi association, businessmen, social workers, a psychiatric nurse from the clinic, a primary school teacher, high school teacher, parents of a mentally handicapped child and a pastor from a church. The University of Limpopo, then the University of the North, proposed the relationship, the objective of which was to establish a centre providing benefits to the community and to the university. This required the involvement of both parties in order to establish a centre for mentally handicapped children. The community representatives agreed to enter into the engagement / relationship. The negotiations took place in phases involving about six meetings so that the community could have a firm grip of the whole exercise. In the fourth meeting, Chief Kgabo Moloto III sent the agricultural staff, who were working in the chief's kraal, to go and demarcate an area of land for Moletši Centre.A plot was already reserved by Chief Kgabo Moloto III for the project.

- Committees

Two committees had been formed: an executive committee (which consists of all sectors of the community) and the parents' committee. These are still functioning up to the present time and the University of Limpopo's representative remains Dr J.C. Kgole (who was chosen as the secretary due to her access to faxes and e-mails), the psychiatric nurse specialist in the Department of Nursing Science. 
- Activities undertaken by the University of Limpopo to assist the Moletši community:

The psychiatric nursing lecturer, together with fourth-year psychiatric students, conducted a mini research study in the Moletši area to identify the number of mentally handicapped children. Random sampling was done and 24 villages were identified. In the selected villages the lower primary schools were targeted. In 24 villages, 100 mentally handicapped children were identified in the villages and lower primary schools. The report was given to the community at the Chief's kraal and the Department of Nursing Science. Psychiatric / mental healthcare was also the focus of a study undertaken between 1999 to 2000 based on the experiences of parents regarding support services for their mentally handicapped children (Kgole, 2000) and this led to the development of a model for the empowerment of families with such children (Kgole, 2010).

A one-and-half room building was erected by the Capricorn District of Polokwane Municipality in the yard of the centre as a base for community activities. The university staff assisted Moletši Centre to secure a fundraising number and the centre was able to secure funds to fence the yard and erect a building. The children are now in the new building. The fourth-year psychiatric nursing students conduct annual home visits to provide health education to the parents regarding the care, treatment and rehabilitation of mentally handicapped children. Psychiatric nursing students also held seminars for the volunteer teachers at the centre to teach them about mental handicaps: the causes, how to recognise a mentally handicapped child, the training of mentally handicapped children in relation to social, occupational, and self-management issues, and the use of leisure time.

The Department of Nursing Science requested the Psychology Department (lecturers and student psychologists) to assess the children at the centre and recommend referral to the psychiatrist for treatment. The psychological reports assisted the centre in applying for financial security for the children. All children at the centre have accomplished this and are able to pay their school fees (Fletcher, 2003).

It has become customary for the Department of Nursing Science to arrange and stage a health education day on mental disabilities in the form of fun days, recognition of everybody's birthday, etc. For the health education day, students raised funds to cater for the people who came to the occasion. Students also brought clothes for the children, as well as buying sweets and cakes for them and asking for donations in the form of stationery to be donated to the centre. On this day, the parents of mentally handicapped children, the children and their care-givers, the chief counsellors, political organisations, nearby schools and projects, the inter-denominationalwomen's league and the community at large honour the occasion. In December 2012, the other organisations that joined the University of LimpopoTurfloop Campus were Loopmatic (Music Company) and Mafia boys (charity organisation from schools in Polokwane). The inter-denominational women's league donate 20 chairs for the centre, utensils, and drums for keeping water, tables and food parcels annually.

- $\quad$ Support

The centre has been supported by the Anglican Church, Polokwane branch from its inception in the form of money, food parcels, prayers and clothes, as well as by other churches in the area. The Department of Social Development donated a sum o R500 000, 00 and a further R400 000, 00 that ceased in the year 2010. Chief Moloto 111 was approached for a donation of R250, 000 for a 2-classroom building and also gave hand donations. The National Development Agency donated a sum of R300 000, 00 for fencing the plot/stand, training volunteers and a committee for the centre, paying monthly stipends for 3 years and 
providing food for the children at the centre. Business organisations in Moletši donate food parcels and monthly donations are received from parents of the mentally handicapped children.

- Achievements of the centre

The education of the community on mental disabilities by the University of Limpopo, Department of Nursing relating to the care, treatment and rehabilitation of mentally handicapped children has been a major achievement. A three-classroom building has been erected and professional nurses and other multi-disciplinary members visit the centre from a nearby clinic and hospital as a result of university negotiations.

Research was undertaken on the experiences of parents with regard to support services and a model of empowerment representing families of mentally handicapped children was developed by the University of Limpopo.

However, the needs of the centre, such as skills training for volunteer teachers, adequate teaching facilities, the appointment of teachers with special training and being able to appoint a Director/Principal for the school remains daunting. It would be ideal to appoint a psychiatric nurse for the centre, especially for the many children with epilepsy, and to have transport facilities for the children.

Due to these needs, Moletši Centre committees and the Chiefs kraal staff, with the assistance of the University of Limpopo's Department of Nursing Science, have applied for the centre to be taken over by the Limpopo Department of Education. Presently, the Department of Education faces a financial challenge but, as soon as this is resolved, the centre may be subsidised.

\section{University of Technology: A case study from Durban University of Technology}

Title: Community-Based Education at the Durban University of Technology: Lifestyle changes through sport

In response to the State President's call for poverty alleviation, as well as the opportunity provided by Atlantic Philanthropies' provision of funding for nursing education in South Africa, the Durban University of Technology (DUT) admitted its first cohort of students to the four-year undergraduate nursing degree programme in January 2010. According to Gwele and Makhanya (2008: 8), the purpose of the four-year B. Tech. Nursing Science programme is to "produce nurses who are competent to function within a district health system, with specific reference to PHC settings. The focus is on relevant, authentic and transformative learning experiences that recognize the significance of sociolinguistic meaning perspectives about health and disease as well as a critical understanding of social, political and economic determinants of health". Hence, a community- and case-based learning programme was launched in 2010. CBE has become a trend in line with the re-engineering of Primary Health Care PHC in the South African health system, where the focus will be on prevention rather than cure. Rethinking in nursing education is necessary to bring about a new world of nursing education (Steiner and Hewett 2010: 11). CBE is a means of achieving educational relevance to community needs, thus implementing a community-orientated educational program. It involves the utilization of the community as a learning environment. The key role-players are students, teachers, community members and representatives from other sectors who are actively engaged throughout the educational experience (Gwele et al., 2003: 22). DUT has responded to this call by incorporating CBE in the undergraduate curriculum from 2010. 
Students spend a semester in each of the first two years of study in community settings. In addition, the second semester of the fourth year is dedicated to primary healthcare settings. Students are placed in four communities, two of which are rural and the other two semi-urban. This allows the students to be exposed to two diverse cultural populations. During the first semester of community placement, students conduct community assessments in order to determine the actual and/or potential health problems that may be facing the communities in which they work. Identified health problems form the core of what is learned in class. Together with the communities, students prioritize and identify a particular problem that they can work with and try to intervene, in collaboration with the communities. This is followed by an evaluation process.

The nursing students who were allocated at Copesville performed the intervention on the 6th of August 2011. They decided to hold a soccer tournament, and the theme for the day was 'Lifestyle changes through sports'. Sports help to promote health in various ways. The community showcased various forms of talent in the form of traditional dance, netball and soccer. On the 6th August 2011, it was a very chilly, snowy day but Copesville Sports Ground was full. Seven soccer teams competed. The teams that won received trophies, shorts for training, bibs that were donated by the KwaZulu-Natal Sports and Recreation Department and medals donated by nursing students. The Copesville councilor welcomed the students and went all out to support the event. Besides soccer, there were groups that danced in between breaks organized by the councilor. She helped to provide food and fruit for the community members and players. The challenges are left with the next group of students who will still work in that community.

\section{Discussion}

In terms of popularity, projects involving health promotion and illness prevention were the most common, followed by projects to improve existing services. This might be related to the fact that the needs in these areas are more easily observed and may seem more open to intervention on the basis of periodic engagement. It might also be because projects around policy development and the provision of new services are much more demanding in terms of competencies, resources and long-term engagement. Nevertheless, it would be useful, especially for research-intensive universities, to become involved in policy development projects.

Furthermore, it is also in these two types of projects that a larger component of academics are involved - on average $24 \%$ for health promotion and illness prevention and $29 \%$ for improving existing services. These are quite impressive percentages if one remembers that many academics are also involved in improving their qualifications by doing PhDs and in undertaking research. It might be interesting to explore whether different academics engage in different activities; for instance, whether the researchers are also involved in communities or not, and whether more experienced academics are involved in community projects to a greater or lesser extent.

The depth and scope of engagement of some of the schools are also impressive. Their work goes on over the years and achieves real service outcomes that make a difference to people's lives. This is particularly important when one considers the demands university academics in nursing already have to deal with 
over and above their teaching and research functions - clinical supervision, maintaining their own clinical competence and assisting with Nursing Colleges and in the profession at large.

In all the project descriptions, the university became responsive to the needs of the community such as pregnancy, mental disability, social pathologies, HIV/AIDS, behavioural problems and domestic violence and took on its social responsibility. Negotiations took place at the beginning to propose the working relationship with different stakeholders. It became evident that university staff became involved in community engagement which they based on the mission and vision of the university. In some cases, the community was selected by the university and more than one school or profession was involved from the start, while in other cases the School of Nursing chose the community and sometimes gradually involved other disciplines.

Both parties, that is the community and the university, tend to benefit from community engagement, For example, the university assisted the community to access the fund raising number in order to gain funding, the nursing students conducted home visits and provided health education. In turn, the university also benefited from the community because the performed tasks such as exposing knowledge to the community enriched nursing students' knowledge and prepared them to become competent and independent nursing practitioners. The projects provided a wide range of learning experiences to students, both in the general field of community health nursing, and in more specific areas such as psychiatric care.

In most of the detailed project descriptions, which were often of a long-term nature, research formed part of the engagement. This was not restricted to research-intensive universities, but was true across the board. It is evident that the roles of university lecturers became evident in community engagement: teaching, research and community work depending on the needs of the community.

\section{Recommendations}

Further research needs to be conducted to explore the understanding and perceptions of nursing schools towards community engagement and to further study the choices made with regard to this kind of activity. An investigation into the impact of these projects will be useful to build evidence regarding the contribution university nursing schools are making to health in the communities.

It would seem that nursing schools need to become involved in projects and initiatives that develop new health policies or advocate for changes to existing policies. This is an aspect of professional practice long neglected by nursing, and there is probably a need for some skills development in this area to equip academics and their students for this role.

\section{References}

Committee on Institutional Cooperation (CIC). 2005. Engaged Scholarship: A Resource Guide. Chicago: $\mathrm{ClC}$ Committee on Engagement.

Council on Higher Education. 2010. Community Engagement in South African Higher Education, Kagisano No 6. Pretoria: Jacana Media. 
Abrahams, M. and Fine, N. 2003. Cooking Up Community. First Edition Change Moves Publication. Daily E Mail Newsletter South Africa, 27 September 2002. Sex Abuse among pupils increasing.

South African Police Service. 2004. Crime Statistical Report. Kuils River.

Erasmus, J., Mans, G. \& Jacobs, C. 2005. Unit for Religion and Development of Stellenbosch University in Partnership with Transformation Africa. Kuils River / Belhar Transformation Project.

Department of Education. 1997. Education white paper 3: A programme for higher education transformation. Government Gazette No. 18207, 15 August 1997. Pretoria: Government Printers.

Fletcher, A. 2003. Information Kit to Support the International Day of the Disabled Persons. 3 December. Belgravia: Disability awareness in Action.

Gibbons, M. 2007. Engagement as a Core Value in a Mode 2 Society. Community Engagement in Higher Education Proceedings of the Conference. 2007 Published by The Council on Higher Education (CHE) Higher Education Quality Committee (HEQC) and JET Education Services (JET) Community - Higher Education - Service Partnerships (CHESP).

Gwele, N.S. \& Makhanya, J. N. 2008. Increasing the Production of Professional Nurses in South Africa: A Proposal for Establishing a Four-Year B. Nursing Program at DUT. Unpublished Proposal Submitted to the Atlantic Philanthropies. Durban: DUT.

Kgole, J.C. 2000. Experiences of the Parents of Mentally Handicapped Children with Regard to Support Services for their Mentally Handicapped Children. Pretoria: Medunsa

Kgole, J.C. 2010. A Model of Empowerment of Families with Mentally Handicapped Children. Pretoria: Unisa.

Kitshoff, D. 2010. Thesis for a Master's degree. The Value of Collaboration in an Integrated Community Development Programme as Experienced by Stakeholders. University of Stellenbosch.

Lazarus, J., Erasmus, M., Hendricks, D., Nduna, J. and Slamat, J. 2008. Embedding Community Engagement in South African Higher Education. SAGE Publications (www.sagepublications.com) Vol 3(1) 59-85

Stellenberg, E.L. 2000. Dissertation for Doctorate Degree. An Investigation into the Factors Influencing the Health Status of the Coloured People in the Western Cape in an Urban Area. University of Stellenbosch. 
Stellenberg, E.L., Welmann, E.B. \& Groenewald J.C. 2008. Investigation into the relationship between the socio-economic and health status of the coloured people of the Western Cape in an urban setting. Curationis 31(2) 50-59.

Stellenberg, E.L. \& Corfield, V. 2013. HIV/AIDS peer education initiative for learners in Kuils River Western Cape, South Africa. African Journal for Physical, Health Education, Recreation and Dance (AJPHERD) 19(1): 69-81.

World Health Organisation. 2003. The World Health Report: Global Health: Today's Challenges. Geneva 